\section{Could closing the gender gap in STEMM really take a quarter of a millenium?}

\author{
Francesca Lake \\ Head of Open Access Publishing, Future Science Group, Unitec House, \\ 2 Albert Place, London, UK; f.lake@future-science.com
}

BioTechniques 65:1 (July 2018) 10.2144/btn-2018-0061

Our news team recently covered research [1] in which a team from the University of Melbourne (Australia) analyzed 10 million academic papers in PubMed and arXiv and concluded that, without immediate action, some of the STEMM disciplines could take up to 250 years to establish gender equality [2].

As reported elsewhere [3], the gap is largest in fields dominated by one gender such as computer science, engineering and physics for men, and nursing for women. The latest study predicted that at the current rate, the gap could take 320 years to close for nursing, 280 for computer science, and 258 for physics. Biotechnology is less bleak, at a little over 13 years.

The authors suggest a number of approaches, many of which surround supporting women with families. Additionally, cultural attitudes will need to change, and publishing be reformed.

The authors have made their dataset available, encouraging follow-up studies to determine whether there is a real, as opposed to assumed, impact of techniques aimed at avoiding bias, such as double-blind peer review, on the gender split of authors. It would also be interesting to use these data to delve into why wealthier countries have a wider gap than poorer ones. Indeed, previous research has suggested that higher social equality is linked to a lower uptake in STEMM careers by women as there's more career freedom and less pressure to take on higher paid career paths [4] - so perhaps, the gap is set to widen.

1. BioTechniques news April 2018. www.future-science.com/btn/news/apr18/15

2. Holman L, Stuart-Fox D, Hauser CE. The gender gap in science: How long until women are equally represented? PLOS Biol. 16(4), e2004956 (2018).

3. Cheryan S, Ziegler SA, Montoya AK, Jiang L. Why are some STEM fields more gender balanced than others? Psychol. Bull. 143(1), 1-35 (2017).

4. Stoet G, Geary DC. The gender-equality paradox in science, technology, engineering, and mathematics education. Psychol. Sci. 29(4), 581-593 (2018).

For Editorial-related queries please contact me at f.lake@future-science.com.

BioTechniques is a peer-reviewed journal dedicated to the publication of original laboratory methods, related technical tools, and methods-oriented review articles that are of broad interest to scientists engaged in basic applied life science research. Complete Instructions for Authors are available at: https://mc04.manuscriptcentral.com/fs-btn, BioTechniques' website for online manuscript submission. All manuscripts should be submitted at this site.

\section{BioTechniques Staff}

Editorial, Production \& Circulation

Chairman: James Drake

Managing Director: Phil Garner

Publisher: Cheryl Wall

Head of Open Access: Francesca Lake

Head of Production: Kathryn Berry

\section{Sales \& Business Offices}

Advertising: Cheryl Wall • cwall@biotechniques.com

Subscriptions: Dominik March • d.march@future-science.com

Reprints: Sam Cavana • s.cavana@future-science.com

List Rental: Leela Ripton・I.ripton@future-science.com

Permissions: Adriana Gonzalez • a.gonzalez@future-science.com

\section{EditorialBoard}

Bill Brizzard, Indiana University Research and Technology Corp.

Bruce Budowle, UNT Health Science Center Piotr Chomczynski, Molecular Research Center Rita R. Colwell, University of Maryland-College Park and Johns Hopkins University

Joshua J. Coon, University of Wisconsin-Madison Manel Esteller, Spanish National Cancer Centre (CNIO) Jeffrey Felton, Western University of Health Sciences Erica A. Golemis, Fox Chase Cancer Center Peter M. Gresshoff, The University of Queensland Yoshihide Hayashizaki, RIKEN

Jörg Hoheisel, German Cancer Research Center Leroy Hood, Institute for Systems Biology

Pui-Yan Kwok, University of California, San Francisco Rachael L. Neve, Massachusetts Institute of Technology Peter J. Oefner, University of Regensburg Stephen W. Paddock, University of Wisconsin-Madison Scott D. Patterson, Amgen, Inc.

Leonard F. Peruski, Jr., Centers for Disease Control John Quackenbush, Harvard School of Public Health Pier Giorgio Righetti, Polytechnic University of Milan John Rossi, City of Hope

Herbert P. Schweizer, Colorado State University Barton Slatko, New England Biolabs

Steve S. Sommer, MEDomics, LLC Igor Stagljar, University of Toronto Mathias Uhlén, The Royal Institute of Technology Timothy Veenstra, SAIC-Frederick, Inc.

Kent E. Vrana, Penn State College of Medicine Michael Weiner, AxioMx 